\title{
Biopolitical subjectification
}

\author{
Ott Puumeister \\ Department of Semiotics \\ University of Tartu \\ Jakobi 2, 51005 Tartu, Estonia \\ e-mail: ott.puumeister@ut.ee
}

\begin{abstract}
The article proposes a semiotic interpretation of the concept of biopolitics. Instead of a politics that takes "life itself" as its object and, as a result, separates life as an object from subjects, biopolitics is read as subjectification - a governmental rationality that constructs social ways of being and forms of life, that is, social subjectivities. The article articulates this position on the basis of two concepts: Jakob von Uexküll's umwelt and Michel Foucault's dispositive. While the former makes it possible to show that the process of life can be conceptualized as subjectification, the latter enables us to argue against an interpretation of biopolitics as a totalized structure of power intervening directly, without semiotic mediation, into "life itself".
\end{abstract}

Keywords: biopolitics; dispositive; umwelt; subject; Jakob von Uexküll; Michel Foucault

\section{Introduction}

This paper is an attempt to take a perspective on biopolitics that is slightly different from the customary. While biopolitics is commonly conceptualized as the reduction of human beings to a less-than-human condition to what is termed either 'bare life' (Agamben 1998) or 'sheer life' (Arendt 1998[1958]), my purpose is to focus on subjectification in its double meaning: both the active and agential construction of subjectivity and subjection in the context of power relations. While problems of subjectivity and subjectification are not entirely absent from the theories of biopolitics, the principal focus of analysis is often on the separation of life from the subjects - on the process through which subjects can be turned into simple living objects to be managed and controlled, or, in the extreme, to be made entirely disposable. 
This focus has two consequences which are also the reasons why I am attempting to think of biopolitics on the basis of subjectification. The first is related to the understanding that biopolitics takes something as vague and indeterminate as "life itself" as its object - either life at the molecular level (see Rose 2007) or the bodily life of humans-as-living beings separated from the latter and thus rendered incapable of any sort of freedom and meaning-making (see Agamben 1998). The consequence of this argument is that here the object of government (the governed) is no longer something that can be conceptualized in terms of agency: it is a mere living object - biosemiotically speaking, a contradiction. The second consequence is directly related both to the first question as well as to the following one: how is it possible to conceptualize resistance in the context of biopolitics if the life governed is separated from the subject and rendered into a passive, controllable process or an object? The answer is often sought in a completely new conceptualization of life that has, unfortunately, next to nothing to do with politics. This is, for example, Agamben's strategy when he envisions a "form-of-life" that "can never be separated from its form" (Agamben 2016: 207) - a form of life that communicates only its (im)potentiality; a life lived in "non-relation" to power: an apolitical life. ${ }^{1}$ What resists is understood to be a life that now separates itself from political (inter)action. As a result, "life itself" or "bare life" is given almost an ontological spontaneous capacity for resisting power: life, simply in its vital process, (re)producing itself, is that which cannot be subjected and which "does politics" spontaneously without a subject (see, for example, the concept of multitude in Hardt, Negri 2000; 2004).

These two consequences are what I will attempt to overcome with a focus on subjectivity and subjectification in the context of biopolitics. This line of argument enables us to conceptualize biopolitics as politics, and not as a simple application of power over life. ${ }^{2}$ That is, if biopolitics is not viewed simply as a

1 When Agamben thinks of politics beyond biopolitics, he posits a non-relational ontology in which living beings could not be reduced to their "relations", but would matter in their very form of life: "It will [...] be necessary to think politics as an intimacy unmediated by any articulation or representation: human beings, forms-of-life are in contact, but this is unrepresentable because it consists precisely in a representative void, that is, in the deactivation and inoperativity of every representation" (Agamben 2016: 237). Agamben's ambition is, then, certainly a utopian one of thinking a politics of everyday singular events of encounter without (representative) power. The aim of this article is, however, not to present a dilemma between political freedom and coercive power, but to articulate how power and politics always coexist and cannot be thought separately. For this purpose, speaking of a politics without power amounts to speaking of an apolitical politics.

2 This is not to say that Agamben does not attempt to think of a sort of "democratic biopolitics" (see Prozorov 2017), but rather that, for him, this would mean a total reconfiguration of what we mean by politics - as noted above, it would necessitate thinking of a politics without power. 
form of government that objectifies "life itself", but that constructs, constitutes and normalizes social subjectivity in its biological and bodily aspects, then we do not need to go to extra lengths in order to endow "life" with an ontological political potentiality. However, I do not wish to understand subjectivity here as something necessarily opposing or standing outside power relations. The point is to show that, instead, subjectivity can be understood to be both constructed in power relations and a site of resistance. The possibility of resistance, and thus of freedom of action, stems precisely from semiotic interaction in the context of power relations.

In order to articulate this point, I will employ two concepts that, at first glance, might seem rather distant from each other and attempt to relate these. The first of these is the dispositive - first proposed by Michel Foucault (1980) and later developed, among others, by Gilles Deleuze (2006) and Giorgio Agamben (2009) which signifies a network of heterogeneous elements deployed to some strategic ends. The dispositive is always related to power and the latter's subjectifying dimension. As a most famous example, the Panopticon constructs its subjects as docile bodies (Foucault 1991[1975]). The second concept is Jakob von Uexküll's (1957[1934]; 1982[1940]) umwelt, a subjective meaningful world through the construction of which living beings also become subjects of their own world. The concept of umwelt enables us to focus on subjectivity while not saying that biopolitics is not, in fact, importantly related to life, because based on Uexküll it is possible to say that the process of life is primarily an ongoing process of subjectification.

Still, before we can turn to the concepts of the dispositive and umwelt, let us briefly consider Hannah Arendt's and Giorgio Agamben's understanding of biopolitics as a totalized and totalizing power in order to know better what it is we are opposing.

\section{Hannah Arendt: The politicization of sheer life}

Both Hannah Arendt, ${ }^{3}$ who attempted to understand the new post-World War II context within which Western people found themselves, and Giorgio Agamben, whose theory of biopolitics based on Foucault's approach ${ }^{4}$ and on a reconceptualization of Carl Schmitt's (2007[1932]) figure of the sovereign gained

\footnotetext{
3 Although Arendt never uses the terms 'biopolitics' or 'biopower', her analysis of the introduction of sheer life into modern politics is the reason why she is considered to be a "theorist of biopolitics avant la lèttre" (Braun 2007: 7).

4 It must be said, however, that Agamben shares much more with Arendt's perspective than with Foucault's (see Blencowe 2010), which is why they are also considered together in this paper.
} 
increased popularity in the wake of 9/11, conceptualize biopolitics as a form of totalized power of subjection. Although Arendt concentrates on the normalization of individuals' behaviour and Agamben on the production of a biopolitical body exposed to sovereign violence, their argument springs from the same source Aristotle's (1995) view of politics as dealing with the good life as opposed to sheer life or life as such, the latter being excluded from the political and confined to the domestic sphere. Consequently, they articulate the problem in the same manner: political freedom of action becomes impossible when sheer life (zoē) becomes the basis for the constitution of a political life (bios).

Let us begin by considering Arendt's view. Her analysis of modern politics is informed by Aristotle's distinction between sheer life and good life that is symmetrical with the division between oikos and polis, the private household and the public affairs of the city. Sheer life, belonging to the private household, deals with the realm of necessity, the satisfaction of everyday needs of human beings. Freedom becomes possible only in the public realm, in the polis. The implication here is that freedom of action becomes possible when one is free from concerns regarding biological needs:

Natural community in the household [...] was born of necessity, and necessity ruled over all activities performed in it. The realm of the polis, on the contrary, was the sphere of freedom, and if there was a relationship between these two spheres, it was a matter of course that the mastering of the necessities of life in the household was the condition for freedom of the polis. (Arendt 1998: 30-31)

Thus, politics, conceptualized along Aristotelian lines as the association of free citizens based on logos, reason and language, cannot involve concerns for the biological aspects of life. The good life does not refer to biological life, it is "'good' to the extent that by having mastered the necessities of sheer life, by being freed from labor and work, and by overcoming the innate urge of all living creatures for their own survival, it was no longer bound to the biological life process" (Arendt 1998: 37).

Now, modernity, according to Arendt, introduces the biological life process and necessity into politics. Modern society can thus be understood as an enlarged household in which sheer life becomes a predominant concern. Politics is, consequently, transformed into management and administration of (biological) necessities that precludes any possibility of creative political action and human beings are relegated to normalized behavior (Arendt 1998: 40). In the words of Hanna Pitkin (2000: 181), behaviour and action can be distinguished in the following manner: 
Behaviour is rule-governed, obedient, conventional, uniform, and status-oriented; action, by contrast, is spontaneous and creative; it involves judging and possibly reversing goals, norms, and standards rather than accepting them as given. Behaviour is routine, action unpredictable, even heroic.

With politics transformed into normalization of behaviour, human beings are transformed into labouring animals - animal laborans as opposed to homo faber (see Arendt 1998: 144-159) - whose sole function is to reproduce sheer life. Arendtian biopolitics understands subjects to be wholly subjected to the normalizing power of society, with the only potentiality for freedom of action understood to stem from mastering the necessities of life and relegating them from politics altogether. Freedom and biopolitics cannot be thought together, since, for Arendt, "there is not an ounce of matter in human action" (Lazzarato 2014: 28).

\section{Giorgio Agamben: The production of bare life}

Agamben's argument is similar to Arendt's. Agamben, too, begins his Homo Sacer. Sovereign Power and Bare Life (1998) with the Aristotelian distinction between $z o \bar{e}$ and bios, life common to all living beings and a politically qualified life of a certain collective of living (human) beings. However, Agamben's argument introduces us to a term signifying a specifically biopolitical product - 'bare life'. It is important to note that for Agamben, $z o \bar{e}$ is already a biopolitical distinction: life excluded from the political sphere and posited as the ground from which human politics becomes possible. Thus, when Agamben speaks of $z o \bar{e}$, he is dealing with a political concept and not with the notion of life common to all living beings: "[I] in Western culture 'life' is not a medical-scientific notion but a philosophico-political concept" (Agamben 2016: 195). ${ }^{5}$

Bare life is thus that which is separated from political life. This inclusive exclusion of bare life marks, for Agamben, a structure of biopolitics which makes it possible to reduce human beings to simple living objects, that is to say, to life that is stripped of all rights and exposed to sovereign violence. Similarly to Arendt, Agamben's main concern is to show how the inclusion of bare life into politics

\footnotetext{
5 This interpretation extends to Aristotle who, according to Agamben (2016: 200), "in no way defines what life is: he limits himself to dividing it thanks to the isolation of the nutritive function, in order then to rearticulate it into a series of distinct and correlative potentials or faculties (nutrition, sensation, thought). [...] What has been separated and divided off (in this case, nutritive life) is precisely what permits one to construct the unity of life as a hierarchical articulation of a series of faculties and functional oppositions, whose ultimate meaning is not only psychological by immediately political."
} 
reduces human beings to a non-human state of life - a state that no longer allows any political freedom.

In contrast to Arendt, however, Agamben searches for an ahistorical or transhistorical structure of biopolitics. The transhistoricity of his argument can clearly be seen in the manner he conceptualizes "Western politics" according to the binary opposition of bare life/political life (see Blencowe 2010). Although he does acknowledge that "modern democracy presents itself from the beginning as a vindication and liberation of $z o \bar{e}$, and that it is constantly trying to transform its own bare life into a way of life and to find, so to speak, the bios of $z o \vec{e}$ " (Agamben 1998: 13), he nevertheless finds already the Greek division to be biopolitical, allowing for the capture of bare life into politics. For Agamben, biopolitics is not so much a modern invention, but an ahistorical structure of Western politics as a whole: "It can even be said that the production of a biopolitical body is the original activity of sovereign power" (Agamben 1998: 11, original italics). This "biopolitical body' is analysed through the figure of homo sacer ${ }^{6}$ - originally a concept in Roman law ${ }^{7}$-, someone who is abandoned from the protection of law and who can be killed with impunity. With respect to the homo sacer, "all men act as sovereigns" (Agamben 1998: 53). The biopolitical body is one that is reduced to bare life and rendered killable. Understanding the whole of Western politics as based on the structure of inclusive exclusion, Agamben can conclude that its fundamental and originary function is desubjectification and objectification of human beings through the separation of bare life from political life. There are, of course, significant problems with this kind of formal and structural conceptualization of politics. In the words of Thomas Lemke (2005), it is, for example, simultaneously too general and too narrow in the sense that it effaces significant insights into technologies of power and, at the same time, reduces politics to one specific structure (see also Coleman, Grove 2008). Katia Genel (2006) provides a similar critique, stating that Agamben's view reduces all of politics to the decision over the value of life.

\section{Arendt and Agamben: Biopolitics as totalized power}

Both Arendt and Agamben underscore the dehumanizing and desubjectifying aspects of biopolitics, stressing that the politicization of life, in fact, makes political action impossible. For Arendt, human beings are normalized and condemned to

6 Homo sacer is another concept posited by Agamben as transcending history, enabling us to interrogate the present (see Fiskesjö 2012).

7 On the meaning of homo sacer, see also Fowler 1911. 
mere reproductive behaviour; for Agamben, they are objectified and rendered killable. Both are prone to totalizing visions of power: Arendt "writes about the social as if an evil monster from outer space, entirely external to and separate from us, had fallen upon us intent on debilitating, absorbing, and ultimately destroying us, gobbling up our distinct individuality and turning us into robots that mechanically serve its purposes" (Pitkin 2000: 4); Agamben (2016: Part III) tells us that the only way to escape the hold of biopolitics is to rethink the concepts of politics and life altogether.

Thus, both conceptualize biopolitics along the lines of total subjection, stripping human beings of the capacity for (self-)construction. Once the biological body enters politics, the latter can no longer be conceptualized as politics. In this way, both Arendt and Agamben seem to perpetuate the idea that "true" politics can only be practised by and among "minds", otherwise it is already perverted into an inhuman quasi-politics. Both Arendt (1998) and Agamben (2000: 3-14; 2016: 214-219) speak of 'thought', 'contemplation' and 'intellect' when conceptualizing the potentiality for political freedom, thus making it seemingly impossible to think of freedom from the perspective of the body, or in other words, from the perspective of that which is politicized in the first place.

Now, when biopolitics is conceptualized as total subjection, the only way to think resistance and freedom that remains is that of escaping from it altogether. For Agamben, who equates Western politics with biopolitics, this task is made all the more difficult since political freedom has to take the form of escaping the millennia-old tradition of politics as a whole. He does this by attempting to get rid of the notion of subjectivity, since, as he explains, "if power relations necessarily refer to a subject," the "ungovernable" cannot be thought based on this concept (Agamben 2016: 108). The concept Agamben coins for conceptualizing an escape from biopolitical sovereignty is the 'form-of-life', a life that cannot be separated from its form, that is, cannot be divided into zoe and bios, into an excluded ground and a politically qualified life. In The Coming Community, published before Homo Sacer, Agamben (2007[1990]) already uses a similar concept to the form-of-life, then called 'whatever being. 'Whatever' does not signify it does not matter which, but that a being described by this term always matters (Agamben 2007[1990]: 1). The form-of-life, or the whatever being, then, is always itself, and never (re)presents anything other than itself, its own potentiality. While attempting to get rid of the notion of subjectivity, Agamben veers alarmingly close to a sort of radical individualism by essentially saying - every way or form of life matters in its very style of being. In the words of Sergei Prozorov (2017), Agamben's means of thinking of freedom and resistance result in a 'democratic biopolitics' which has rendered sovereign biopolitics inoperative. 
What risks getting lost in this juxtaposition of a totalized sovereign power and a life that always matters is, however, the dimension of power. And with losing sight of power, we are also at risk of losing sight of politics. For what politics can we speak of if the form of association of living beings is simply a communication without interaction and conflict, a form of association which merely lets beings be as they are in themselves, as they go about their business in whatever form? The result of Agamben's strategy of thinking freedom and resistance without subjectivity might very well lead to a vision of an apolitical politics ${ }^{8}$ in which every form-of-life is, paradoxically, again, its own sovereign in that they can be whatever they prefer to be - or prefer not to. It must be said, however, that the term 'individuality' does not suit Agamben's thought very comfortably, at least in its traditional sense of an individual human being with a (relatively) fixed identity. Nevertheless, if the term is taken literally as something that cannot be divided, then a 'form-of-life' cannot be anything other than an individual. ${ }^{9}$

In the following, I will attempt to think of freedom and resistance in the context of biopolitics without trying to escape relations of power. Instead, it would be necessary, especially if biopolitics is to be a useful concept for a semiotic perspective on society and politics, to maintain that power is not a totalized structure of subjection and that resistance is to be thought of within the context of power relations, not radically outside them. This argument entails the view of subjectivity that is necessarily always something other than itself - conditioned and, to an extent, constituted within power relations -, while at the same time still exercising the (potentially political) freedom of self-construction. Thus, we cannot oppose an integral 'form-of-life' to a totalized power as if they were outside each other. To explain this further, let us move to the concepts of dispositive and umwelt.

8 As Stefano Franchi (2004: 38) says, Agamben's political thought can very easily become a thought of the "impossibility of politics".

9 To explain the "stylistics" of forms-of-life, Agamben constructs a novel ontological perspective - modal ontology, "the ontology of the how" (Agamben 2016: 231) that does not divide being into Being and beings, but only concerns the ways in which beings exist. By concentrating on the how, Agamben moves from questioning identity to habits, thus his ontology can be called non-identificational. Consequently, he also shifts the meaning of the term 'individual' (although, of course, he refrains from using it himself), which can now signifiy, for example, a gesture, a (bad or good) habit... essentially precisely whatever, since individuality can no longer be conceptualized as a stable identity. It is now an entirely contingent event without a transcendental dimension according to which it could be carved into properties, characteristics, etc. In this sense it is precisely pertinent to speak of radical individualism, because forms-oflife are contingent events defined in their own immanence (see Agamben 1999: 220-233). 


\section{Biopolitics as politics: Disposing the umwelt}

Now, without denying that the introduction of life into politics can be destructive of subjectivity (in the sense of objectifying some human beings as non-humans) and deadly, ${ }^{10}$ it would nevertheless be necessary to conceptualize biopolitics in terms of how Foucault (1982: 790) has understood government - the structuration of "the possible field of action of others". The word 'possible' is the key here, since it leaves open the possibility of freedom in the context of power relations, a possibility of resistance:

[W] hat defines a relationship of power is that it is a mode of action which does not act directly and immediately on others. Instead, it acts upon their actions: an action upon an action, on existing actions or on those which may arise in the present or the future. [...] a power relationship can only be articulated on the basis of two elements which are each indispensable if it is really to be a power relationship: that "the other" [...] be thoroughly recognized and maintained to the very end as a person who acts; and that, faced with a relationship of power, a whole field of responses, reactions, results and possible inventions may open up. (Foucault 1982: 789)

Thus, biopolitical government exhibits what Frederick Dolan (2005) has called the "paradoxical liberty of bio-power": if the human being is cut up, classified, captured into dispositives of power in ways involving biological processes and bodily characteristics, this is not necessarily a reduction, but simultaneously an opportunity to construct social relations and subjects along new trajectories: "the spread of this mode of 'government' tends to increase opportunities for political action that takes the form of questioning, contesting, and resisting the status quo" (Dolan 2005: 373).

Foucault takes a different approach to biopolitics than Arendt and Agamben. Where Arendt saw total normalization of behaviour and Agamben a totalized structure of sovereign violence, the Foucauldian perspective stresses that power should not be viewed as a totality, but itself contingent and in constant change.

\footnotetext{
10 Despite focussing on the productive aspects of biopower, Foucault does acknowledge that the sovereign right to kill has not disappeared, but in the context of biopolitics must be justified on the basis of protecting life instead. In Society Must Be Defended, Foucault (2003a: 256) discusses the link of productive biopolitics and deadly sovereignty from the perspective of racism, saying that if "the power of normalization wished to exercise the old sovereign right to kill, it must become racist". The politics of death (thanatopolitics) is, thus, the other side of the politics of life.
} 
It is here that the concept of the dispositive ${ }^{11}$ becomes important. Foucault uses this concept in order to move beyond a discursive analysis of knowledge to a conceptualization of power as a productive process. It could be said that the dispositive is inseparably tied to biopolitics, because Foucault used it in reference to, among others, the prison where individual bodies are subjected to power (Foucault 1991[1975]), psychiatric power where the category of abnormal individuals is constructed (Foucault 2003b; 2006), and sexuality which is a crucial site of the government of populations (Foucault 1978). The reference to biopolitics is also stressed by an interpretation of the concept by Agamben (2009: 13): "I wish to propose to you nothing less than a general and massive partitioning of beings into two large groups or classes: on the one hand, living beings (or substances), and on the other, apparatuses in which living beings are incessantly captured". Thus, the dispositive is that network of power relations in which humans as living beings are captured.

It is important to note that the dispositive could contain absolutely anything; it is not confined to language, but also entails materiality; it is not confined to human actions, but also has as an important component non-human agency: ${ }^{12}$ the dispositive is a network of heterogeneous elements defined by the nature of relations between these elements (Foucault 1980: 194-195). How can the nature of these relations be determined? According to Foucault, the dispositive always has a strategic aspect; that is, the elements related are deployed to some specific ends; it always "has as its major function at a given historical moment that of responding to an urgent need" (Foucault 1980: 195, original emphasis). Thus, dispositives cannot be generalized into transcendent and total structures of power, they are historical and contingent, they are constantly (re)invented and (re)produced. Furthermore, there can be no single dispositive governing all sociopolitical elements. In any given society, there is always a multiplicity of dispositives all with their specific forms of (normalized) subjectivity. To resist, to form a subjectivity - or a form of life - not previously described and determined within a dispositive does not, then,

11 The French word for the concept is 'dispositif, which is commonly translated as 'apparatus' and sometimes also as 'deployment'. Here I use the term 'dispositive' throughout for reasons similar to those articulated in Bussolini 2010 and Raffnsøe et al. 2014 - namely that this term has a wider scope and refers to the logic of a network of relations, while 'apparatus' is more closely related either to technology in the narrow sense or to 'state apparatuses' in Althusser's (1971) sense.

12 In Maurizio Lazzarato's words: "Machines, objects (and signs), act in precisely the same way as an "action upon action" [...]. This must not be understood merely as a relation of one human being with another. Non-humans contribute just as humans do to defining the framework and conditions of action. One always acts within an assemblage, a collective, where machines, objects, and signs are at the same time "agents"' (Lazzarato 2014: 30). 
require a flight from a grand biopolitical dispositive, but can be conceptualized along the lines of active subjectification in the context of multiple dispositives. That is, active subjectification - self-construction - is that which enables us to speak of a biopolitics - and it does not matter if subjectification is not free from biological concerns. Subjectification can be political in all of its aspects, whether bodily or "rational" - as long as it has the potential to reconfigure the strategic determination of relations between elements.

Now, subjectivity is a product and construct of dispositives of power, and insofar as subjectivity is one of the defining dimensions of dispositives (Deleuze 2006), the latter is primarily a useful analytical concept for understanding the social control and modification of behaviour and self-construction (Raffnsøe 2008). It is also helpful for conceptualizing biopolitics in more semiotic terms and not as simply modifying or practicing violence over life - as a semiotically mediating and mediated power. In the words of André Berten (1999: 42), "Dispositives are a way of understanding human being's natural or constructed environment not as a space of knowledge acquisition and transmission, but as a network that mediates knowledge [...]". If we think of humans as living beings, then it is necessary to note that they always subjectify themselves in an environment that also acts upon them and has already normalized the ways in which they can become social subjects. To become a subject that knows always already entails assuming, at least to a certain extent, of a subject position that is known.

Now, to take seriously the notion of dispositive as a network of heterogeneous elements would necessitate moving beyond "linguistic imperialism" in social semiotics (McDonald 2013), or in other words, not to model political subjectivity on the basis of linguistic-symbolic speech only. We would do well to get rid of the attitude, voiced by George Herbert Mead (1972[1934]: 136), that the "ability to experience different parts of the body is not different from the experience of a table". This perspective implies a relation of ownership of the self over its body, the former commonly understood as reflexive and the latter as simple "material" on which the self is built. This results in the conceptualization of a semiotic self to which the body matters only insofar as it makes the former possible, while the self is symbolically constituted (e.g., Wiley 1994).

However, what do Uexküll and his concept of the umwelt have to do with any of this? It is my proposal that the object of biopolitical government be conceptualized not as "life itself" - which is extremely vague and indeterminate -, but as an umwelt. That is, dispositives of power act as historical conditions of possibility for the construction of social subjectivity. Umwelt, a subjectively meaningful universe (Uexküll 1957[1934]; 1982[1940]), an environment delimited by the network of subjective semiotic relations, cannot be thought of outside dispositives. 
Uexküll resisted the mechanicist perspective on life and living beings (see Brentari 2015: 47-54), stating, for example, that it would be deceptive to "concede to a mechanist, and not a biologist, the right to limit the study of the reality of all living organisms to the law of the Conservation of Energy" (Uexküll 1982[1940]: 26). For him, "Behaviors are not mere movements or tropisms [...]; they are not mechanically regulated, but meaningfully organized" (Uexküll 1982[1940]: 26). Uexküll saw that meaning-making is characteristic of all living beings and in this sense his theoretical biology is fundamentally egalitarian: all living beings should be seen as creators of meaning not reducible to simple mechanical reflexes and reactions: "Depending upon its nature, the simplest reflex is a perception-effect operation, even if its arc only consists of a chain of individual nerve cells" (Uexküll 1982[1940]: 34). His view that even the simplest reflex is of a semiotic nature - it presupposes the conferring of meaning upon that which is reacted to - leads him to postulate that even the simplest living beings possess an umwelt: "We are forced to attribute an Umwelt, however limited, to the free-living fungus-cells, an Umwelt common to each of them, in which bacteria contrast with their surroundings, as meaning-carriers, as food and, in doing so, are perceived and acted upon" (Uexküll 1982[1940]: 35). Extended in this manner, meaning-making becomes the foundational process of biology, but not meaning-making in an abstract sense, but specifically tied to the subject and the process of subjectification: the Uexküllian umwelt emphasizes the role of the subject in the construction and constitution of its very own specific universe; life assumes the form of subjectification.

However, in attempting to provide subjectification in an umwelt with a political dimension, we run into a difficulty. Uexküll understood behaviour in an umwelt according to the concept of 'building-plan' (Bauplan) (1982[1940]: 30) - living beings behave according to a fixed and unchangeable structure. Uexküll, thus, can be seen as a "fixist" (see Brentari 2015: 114). This aspect is criticized by Agamben in his book The Open (2004) in which he interprets the concept of the umwelt as reducing the living being to its functions. Agamben reads Uexküll's famous account of the tick's umwelt as stating that the being of the tick is the relationship between the three elements that enable its movement: the butyric acid, the temperature of 37 degrees, and the skin of mammals (Agamben 2004: 47). There seems to be no escape from an umwelt that is fixed and determined. Characteristically, Agamben proposes that it is necessary to envision a living being "without a world", without an umwelt, in order to think of any sort of freedom. He relies on Martin Heidegger's concept of 'profound boredom' in order to argue for a cut, a rupture in the relationship between the living being and its world: the possibility of not being tied down to a world in which one would simply be defined by its functions. There is no space here to go into a detailed account of this 
interpretation; suffice it to simply underscore the opposition it creates: on the one side, we have the umwelt which defines living beings according to the functioning, and on the other, the 'profoundly bored' living being capable of being cut off from its environment, and thus capable of true self-creation apart from its immediate surroundings.

This is, perhaps, a false opposition, because it is not at all certain that we need to think of a radical cut from the umwelt in order to think of freedom (of behaviour, meaning-making, action, etc.). ${ }^{13}$ In Frederik Stjernfelt's terms, in order to think outside the "perfect fit" between the organism and umwelt, it is necessary to acknowledge the existence of neutral objects, that is, objects not yet given meaning, in the umwelt (Stjernfelt 2007: 261). Without the existence of neutral objects, no learning, no modification of behaviour would be possible. This perspective enables us to understand that the possibility of learning and thus semiotic freedom also open up the living being - the body as a "semiotic device" (Stjernfelt 2007: 261) to normalizing power, biopolitics. Why? If the living being and the umwelt were connected in a "perfect fit", it would not be possible to modify this relation, to introduce into the umwelt subjects and objects as potentially significant for the living being. If we assume the existence of neutral objects, umwelt becomes open: it can be modified by the subject who simultaneously modifies its own behaviour - its own subjectivity. ${ }^{14}$ Thus, the "governed" of biopolitical normalization is necessarily a "normative" (on this notion, see Canguilhem 1991[1966]) living being, capable of constructing and creating its own norms.

When biopolitics, thus, takes the "life" of humans-as-living-beings as its object, it is not to be understood in a way that biopolitical government renders human beings incapable of social meaning-making. With the concept of the umwelt, it is possible to show that the process of life inevitably involves a normative dimension in subjectification. According to this reading, it is not necessary to postulate that "life itself" is capable of resisting biopolitical dispositives: resistance and freedom is exercised by living beings as subjects, and not as an anonymous vital process. And, perhaps paradoxically, it is this semiotic freedom to modify behaviour - change the nature of semiotic relations and resignify objects - that enables something like

13 In addition, thinking of self-construction in terms of a radical cut from a living being's umwelt would very easily lead to a postulation of a sort of disembodied creature of thought who would be capable of simply thinking itself free. In order to conceptualize a biopolitical subjectivity, this is not, however, a fruitful path, since it tends to reproduce the mind vs. body dichotomy in which the former governs over the latter and in which the mind, consequently, assumes the determining role.

14 On the openness of umwelt, see also Maurice Merleau-Ponty's interpretation of the concept in La nature (1995[1968]). 
biopolitics (that is, the government of biological and bodily aspects of individuals) to capture living beings in dispositives in the first place: normativity makes normalization possible, but the latter should not be seen as erasing normativity, but instead as constantly reacting to the creation of norms by living beings (see Mills 2013). Dispositive, thus, is not to be understood as a coherent and total structure, but as Philippe Verhaegen (1999: 112) says, a "techno-semiotic bricolage": a mixture of human and non-human agencies acting upon the actions of subjects, and modifying and constructing their umwelt in the process.

While the Uexküllian umwelt emphasizes the role of the subject in the construction and constitution of its very own specific universe; life assumes the form of subjectivation, thus enabling us to cast aside the vague notion of "life itself" which is too readily reducible to "bare life". The dispositive stresses that the constitution of a subjective universe is always a political activity interwoven with power relations and objectifications of subjectivity. Whenever the social umwelt is analysed, it is not enough to stress the subjective construction of meanings. Complementing umwelt theory with the concept of the dispositive allows us to consider that the elements and relations that become meaningful for the subject are not neutral, but embedded in power relations. Reverting the perspective and conceptualizing the dispositive in terms of the umwelt, allows us to notice the active participation of individuals as living beings - and not as predominantly "rational" or speaking beings, when analysing social mechanisms of subjectification.

\section{A semiotic perspective on biopolitics}

Instead of opposing oppressive biopolitics and a resistant life, it would thus be more useful to conceptualize biopolitics in terms of subjectification. Especially because we would thus be more attuned to the manners in which human ways of life are always politically charged, and not heroically opposed to politics - the latter perspective, as said above, tending to fall back onto an opposition between totalized mechanisms of power and radical individualism. Furthermore, if we oppose life and politics, we run into the risk of conceptualizing a 'life itself' which should not be politicized - the consequence here is that we would tend to interpret any sort of introduction of bodily and biological aspects into political strategies as a sort of perverted politics, not properly human politics. ${ }^{15}$ Political semiotics has taught us

15 That political freedom of action cannot be thought alongside biopolitics, is not limited to Arendt and Agamben, but is present, too, in most theorists concerned with emancipatory politics. Alain Badiou, for example, in his book Ethics (2001), clearly opposes mere life-assurvival to subjectivation according to fidelity to an event (see also Puumeister 2018a); Jacques 
that nothing is political in and of itself; anything, however, can become political once it is constituted as an element in the public sphere (Selg, Ventsel 2008). As also Foucault has put it: although inherently "nothing is political, everything can be politicized, everything may become political. Politics is no more or less than that which is born with resistance to governmentality [...]" (cited in Senellart 2007: 390). This perspective precludes any a priori delimitation of the private and the public (as in Arendt's case: the good life is public and sheer life private). Instead, the very limits between the public and the private are the result of political struggle.

Thus, if the biological and bodily aspects of human life are evidently sites of political struggle and confrontation, it would not make sense to state that they cannot be introduced into politics without the latter becoming reduced to a nonhuman quasi-politics. What should be done, then, with such processes that Paul Rabinow (1996) has termed 'biosocialities' - the construction of social subjects and communities with reference to a specific, often pathological, biological issue? Denying the political nature of struggles based on bio-aspects would amount to stripping certain subjects of their social meaning-making potentiality. A denial of the political nature of these subjectification processes can only spring from the paradigm of humanist politics, that is, from that which understands politics based on language, speech, reason (logos). When biopolitics is understood as taking as its governed subject not life itself, but instead the subjective umwelt, it is possible to conceptualize an image of biopolitics that does not reduce life to a mere cog in the biopolitical machine. In short, the biosemiotic understanding of life as subjectification (the ongoing construction of an umwelt by the organism) enables us to understand the vital process itself in an almost political sense: to live means to constantly interpret and negotiate one's subjectivity in relation to an environment and to other living beings. To live means constantly to choose between simultaneously present alternatives - in short, to make meaning (Kull 2015). The mechanism of choice underlying semiosis is a precondition for freedom of action and cannot be limited to human rational action. Insofar as meaning-making is the activity of life, the latter cannot be conceptualized along the lines of blind obedience to laws; as opposed to obeying physical laws, the formation of habits based on rules is a creative activity (Hoffmeyer 2008; Kull 2014; Emmeche, Kull 2011). If biopolitics is understood to be normalizing, it first and foremost works on constructing habitual behaviour in dispositives of power. Normalization does not, thus, eliminate freedom of choice, although it no doubt

Rancière (2010), for his part, has opposed politics to biopolitics, the latter being a simple process of control over bodies. Biopolitics is seen as an activity of administration, classification, management, control, etc. that has nothing to do with freedom of action. 
constitutes some forms of behaviour as more natural or even as "innate" (e.g., in the form of "sexual drives" (Davidson 1987). This does not mean, however, that political action becomes impossible - the potentiality for semiosis remains (e.g., the emancipatory politics of sexuality constituting the latter as a sociopolitical rather than a "natural" or "innate" phenomenon).

The political nature of human life becomes especially clear when we do not draw a strict line between the natural and the social or political in the modern sense as conceptualized by Bruno Latour (1993): the 'natural' as operating according to laws and the 'social' as the domain of meaning-making. The challenge, when conceptualizing a semiotic understanding of biopolitics, is exactly to understand the bodily aspects and practices as thoroughly semiotic, that is, as an important part of the public exercising of politics. That is, political subjectivity should not be understood according to the concept of the human person, which implies a separation between the rational (speaking) part of the human being and the passional (bodily) part (see Esposito 2012; 2015). This perspective would still put us in the position of differentiating between the social and the natural - and would necessitate that we speak of biopolitics as mere power over the non-semiotic aspects of life. The biosemiotic approach, to the contrary, enables us to view the body itself as actively making meaning (see Stjernfelt 2007; Violi 2008) and thus constitutive of subjectivity. ${ }^{16}$

The view of life as a process of meaning-making and modelling (interpretation) has two significant consequences for conceptualizing freedom in biopolitics: firstly, life is never "sheer" or "bare" life, ${ }^{17}$ but always already a particular perspective undergoing subjectification; and secondly, that which can be conceptualized as resisting power is not "life in general" or "life itself", but an activity of meaning-making, a construction of a particular mode of life. Potentially, thus, any form or mode of life is political or, in other words, always constructing for itself a world of action and interaction via meaning-making processes. And it would not be sensible to try and attempt to limit human politics simply to the activity of speech and reason, since in this way political analysis would remain blind to an abundance of phenomena and processes obviously significant to the constitution of the political sphere. Taking a semiotic perspective on biopolitics thus has the potential to develop an image of biopolitics as posthuman politics - instead of understanding the politicization of human life as precluding political freedom. This would require that we take the body seriously in its political aspects, and not subordinate it to the individual person. This task remains to be tackled in future research.

16 We have previously argued for the necessity to rethink political subjectivity in biosemiotic terms in Puumeister, Ventsel 2018, taking into account the Peircean typology of signs as icons, indexes, and symbols.

17 See also Abbott 2012. 


\section{In place of a conclusion: Some problems concerning our interpretation}

Proposing that biopolitics operates through semiotic mediation on the subjective umwelt and thus is productive of subjectivity creates some problems that require further qualification of what we mean by biopolitics. The principal novelty of the concept of biopolitics is that it articulates the way in which biological life becomes a part of the political process, the latter having previously been understood to be a matter of communication, reason, speech, etc. Now, if we focus on subjectification, will this not reduce the novelty and smooth out the break that the perspective of biopolitics introduced into political theory? What does it mean to say that subjectification is, precisely, biopolitical? Which type of politics does not affect the umwelt of humans-as-living beings? Does not any type of politics construct its own subjects?

The answer to the latter question is, of course, affirmative. Which is why it is necessary seriously to limit the scope of the term biopolitics. I have previously proposed (Puumeister 2016; 2018b) that biopolitics should be understood in the context of specifically normalizing dispositives. More precisely, this means that biopolitics should be understood as constructing ways of being and forms of life that are inherently normalizable: the primary operation of biopolitics is thus to construct abnormality. This means that certain social ways of being are seen as in need of correction and modification, but also of control and management in order that they would conform to the set norms in the future. Now, the principal normalizing technique is the subjects' internalization of the norms for social ways of being. In this way, it is possible to speak of biopolitical self-government: one has to normalize one's being in such a way as to become an acceptable and recognizable social subject. Biopolitics works, then, on the very being of subjects by constructing normalized ways of being in an environment. It does not work on social relations in the strict sense - as in group relations, hierarchies, etc. -, but instead on the body as a normative "semiotic device".

Limiting biopolitics to normalizing techniques of power will no doubt take away some of the concept's novelty and grandeur. It is no longer possible to speak of a total event of modernity through which all politics could be analysed and theorized. However, setting some limits is inevitable in order for the concept to attain its analytical specificity. ${ }^{18}$

18 Acknowledgements. This research was supported by the University of Tartu ASTRA Project PER ASPERA, financed by the European Regional Development Fund, and the Estonian Research Council grant PRG314. 


\section{References}

Abbott, Mathew 2012. No life is bare, the ordinary is the exceptional: Giorgio Agamben and the question of political ontology. Parrhesia 14: 23-36.

Agamben, Giorgio 1998. Homo Sacer: Sovereign Power and Bare Life. Stanford: Stanford University Press.

- 1999. Potentialities: Collected Essays in Philosophy. Stanford: Stanford University Press.

- 2000. Means without End: Notes on Politics. Minneapolis: University of Minnesota Press.

- 2004. The Open: Man and Animal. Stanford: Stanford University Press.

- 2007[1990]. The Coming Community. Minneapolis: University of Minnesota Press.

- 2009. What Is an Apparatus? and Other Essays. Minneapolis: University of Minnesota Press.

- 2016. The Use of Bodies: Homo Sacer IV, 2. Stanford: Stanford University Press.

Althusser, Louis 1971. Ideology and ideological state apparatuses (notes towards an investigation). In: Lenin and Philosophy and Other Essays. New York: Monthly Review Press, 127-186.

Arendt, Hannah 1998[1958]. The Human Condition. Chicago: The University of Chicago Press. Aristotle 1995. Politics. Books I and II. (Saunders, Trevor J., trans.) Oxford: Clarendon Press.

Badiou, Alain 2001. Ethics: An Essay on the Understanding of Evil. London: Verso.

Berten, André 1999. Dispositif, médiation, créativité: petite généalogie. Hermès 25(3): 31-47.

Blencowe, Claire 2010. Foucault's and Arendt's 'insider view' of biopolitics: A critique of Agamben. History of the Human Sciences 23(5): 113-130.

Braun, Katharine 2007. Biopolitics and temporality in Arendt and Foucault. Time \& Society 16(1): 113-130.

Brentari, Carlo 2015. Jakob von Uexküll: The Discovery of the Umwelt between Biosemiotics and Theoretical Biology. Dordrecht: Springer.

Bussolini, Jeffrey 2010. What is a dispositive? Foucault Studies 10: 85-107.

Canguilhem, Georges 1991[1966]. The Normal and the Pathological. New York: Zone Books.

Coleman, Mathew; Grove, Kevin 2009. Biopolitics, biopower, and the return of sovereignty. Environment and Planning D: Society and Space 27(3): 489-507.

Davidson, Arnold I. 1987. Sex and the emergence of sexuality. Critical Inquiry 14(1): 16-48.

Deleuze, Gilles 2006. What is a dispositif? In: Two Regimes of Madness. Texts and Interviews 1975-1995. New York: Semiotext(e), 338-348.

Dolan, Frederick M. 2005. The paradoxical liberty of bio-power: Hannah Arendt and Michel Foucault on modern politics. Philosophy \& Social Criticism 31(3): 369-380.

Emmeche, Claus; Kull, Kalevi (eds.) 2011. Towards a Semiotic Biology: Life Is the Action of Signs. London: Imperial College Press.

Esposito, Roberto 2012. Third Person: Politics of Life and Philosophy of the Impersonal. Cambridge: Polity Press.

- 2015. Persons and Things: From the Body's Point of View. Cambridge: Polity Press.

Fiskesjö, Magnus 2012. Outlaws, barbarians, slaves: Critical reflections on Agamben's homo sacer. HAU: Journal of Ethnographic Theory 2(1): 161-180.

Foucault, Michel 1978. The History of Sexuality, Vol. I. An Introduction. New York: Pantheon Books.

- 1980. The confession of the flesh. In: Power/Knowledge. Selected Interviews and Other Writings 1972-77. New York: Pantheon Books, 109-133. 
- 1982. The subject and power. Critical Inquiry 8(4): 777-795.

- 1991[1975]. Discipline and Punish: The Birth of the Prison. London: Penguin Books.

- 2003a. Society Must Be Defended. Lectures at the Collège de France 1975-76. New York: Picador.

- 2003b. Abnormal. Lectures at the Collège de France 1974-75. London: Verso.

- 2006. Psychiatric Power. Lectures at the College de France 1973-74. Basingstoke: Palgrave Macmillan.

Fowler, W. Warde 1911. The original meaning of the word sacer. The Journal of Roman Studies 1: 57-63.

Franchi, Stefano 2004. Passive politics. Contretemps 5: 30-41.

Genel, Katia 2006. The question of biopower: Foucault and Agamben. Rethinking Marxism 18(1): 43-62.

Hardt, Michael; Negri, Antonio 2000. Empire. Cambridge: Harvard University Press.

- 2004. Multitude: War and Democracy in the Age of Empire. New York: The Penguin Press.

Hoffmeyer, Jesper 2008. Biosemiotics: An Examination into the Signs of Life and the Life of Signs. Scranton: University of Scranton Press.

Kull, Kalevi 2014. Physical laws are not habits, while rules of life are. In: Thellefsen, Torkild; Sørensen, Bent (eds.). Charles Sanders Peirce in His Own Words: 100 Years of Semiotics, Communication and Cognition. (Semiotics, Communication and Cognition 14.) Boston: Mouton de Gruyter, 87-94.

- 2015. Semiosis stems from logical incompatibility in organic nature: Why biophysics does not see meaning, while biosemiotics does. Progress in Biophysics and Molecular Biology 19(3): 616-621.

Latour, Bruno 1993. We Have Never Been Modern. Cambridge: Harvard University Press.

Lazzarato, Maurizio 2014. Signs and Machines: Capitalism and the Production of Subjectivity. Los Angeles: Semiotext(e).

Lemke, Thomas 2005. "A zone of indistinction" - a critique of Giorgio Agamben's concept of biopolitics. Outlines 7(1): 3-13.

McDonald, Edward 2013. Embodiment and meaning: Moving beyond linguistic imperialism in social semiotics. Social Semiotics 23(3): 318-334.

Mead, George Herbert 1972[1934]. Mind, Self, and Society: From the Standpoint of a Social Behaviorist. Chicago: The University of Chicago Press.

Merleau-Ponty, Maurice 1995[1968]. La nature. Cours du Collège de France. Paris: Éditions du Seuil.

Mills, Catherine 2013. Biopolitical life. Södertörn Philosophical Studies 14: 73-90.

Pitkin, Hanna Fenichel 2000. The Attack of the Blob: Hannah Arendt's Concept of the Social. Chicago: The University of Chicago Press.

Prozorov, Sergei 2017. Living à la mode: Form-of-life and democratic biopolitics in Giorgio Agamben's The Use of Bodies: Philosophy and Social Criticism 43(2): 144-163.

Puumeister, Ott 2016. Why does 'normalization' matter to political semiotics? In: Bennett, Tyler James; Rodriguez Higuera, Claudio Julio (eds.). Concepts for Semiotics. Tartu: Tartu University Press, 123-132.

- 2018a. Erandlikkuse eetika [Ethics of exceptionality]. Akadeemia 3: 543-555.

- 2018b. On Biopolitical Subjectivity: Michel Foucault's Perspective on Biopolitics and Its Semiotic Aspects. (Dissertationes Semioticae Universitatis Tartuensis 31.) Tartu: Tartu University Press. 
Puumeister, Ott; Ventsel, Andreas 2018. Biopolitics meets biosemiotics: The semiotic threshold(s) of anti-aging interventions. Theory, Culture \& Society 35(1): 117-139.

Rabinow, Paul 1996. Artificiality and enlightenment: From sociobiology to biosociality. In: Essays on the Anthropology of Reason. Princeton: Princeton University Press, 91-111.

Rancière, Jacques 2010. Biopolitics or politics? In: Dissensus: On Politics and Aesthetics. London: Continuum, 91-96.

Raffnsøe, Sverre 2008. Qu'est-ce qu'un dispositif?: Lanalytique sociale de Michel Foucault. Symposium: Revue canadienne de philosophie continentale 12(1): 44-66.

Raffnsøe, Sverre; Gudmand-Høyer, Marius; Thaning, Morten S. 2014. Foucault's dispositive: The perspicacity of dispositive analytics in organizational research. Organization 23(2): 272-298.

Rose, Nikolas 2007. The Politics of Life Itself: Biomedicine, Power, and Subjectivity in the TwentyFirst Century. Princeton: Princeton University Press.

Schmitt, Carl 2007[1932]. The Concept of the Political. Chicago: The University of Chicago Press.

Selg, Peeter; Ventsel, Andreas 2008. Towards a semiotic theory of hegemony: Naming as hegemonic operation in Lotman and Laclau. Sign Systems Studies 36(1): 167-183.

Senellart, Michel 2007. Course context. In: Foucault, Michel. Security, Territory, Population. Lectures at the Collège de France 1977-78. New York: Picador, 369-401.

Stjernfelt, Frederik 2007. Diagrammatology: An Investigation on the Borderlines of Phenomenology, Ontology, and Semiotics. Dordrecht: Springer.

Uexküll, Jakob von 1957[1934]. A stroll through the worlds of animals and men. In: Schiller, Claire H. (ed.). Instinctive Behavior: The Development of a Modern Concept. New York: International Universities Press, 5-80.

- 1982[1940]. Theory of meaning. Semiotica 42(1): 25-82.

Verhaegen, Philippe 1999. Les dispositifs techno-sémiotiques: signes ou objets? Hermès 25(3): 109-121.

Violi, Patrizia 2008. Beyond the body: Towards a full embodied semiosis. In: Frank, Roslyn M.; Dirven, René; Ziemke, Tom; Bernárdez, Enrique (eds.). Body, Language and Mind Volume 2: Sociocultural Situatedness. Berlin: Mouton de Gruyter, 241-264.

Wiley, Norbert 1994. The Semiotic Self. Cambridge: Polity Press.

\section{Биополитическая субъективация}

Статья предлагает семиотическую интерпретацию понятия биополитики. Вместо политики, которая берет “самое жизнь” в качестве своего объекта и в результате отделяет жизнь как объект от субъектов, биополитика понимается как субъективация - правящая рациональность, которая конструирует социальные способы бытия и формы жизни, то есть социальные субъективности. Аргументация строится на основе двух понятий: умвельт Якоба фон Икскюля и диспозитив Мишеля Фуко. Если первое позволяет показать, что процесс жизни может осмысливаться как субъективация, то второе позволяет трактовать биополитику как беспрерывную конструкцию нормализованной и нормализирующей социальной среды. В конце статьи делается вывод о том, что то, чем биополитика управляет, можно осмыслить как субъективный умвельт, а не в качестве объективной «самой жизни». 


\section{Biopoliitiline subjektistamine}

Artikli eesmärk on tuua kokku biopoliitika teooria ja semiootika. Sel otstarbel tuleb ümber mõelda, mis õigupoolest on biopoliitilise valitsemise objektiks ehk valitsetavaks. Selle asemel et käsitleda viimast 'elu enese' mõiste abil - mis on liiga ähmane ning mida kasutades hakkab biopoliitika tähistama sellist võimu, mis justkui eraldaks elu ja subjektid -, pakub artikkel välja keskendumise subjektistamistele ja subjektsusele. Argument esitatakse kahe mõiste abil. Esiteks, Michel Foucault’ töödest lähtuv dispositiiv, mis võimaldab mõista biopoliitikat pideva normaliseeritud ja normaliseeriva sotsiaalse keskkonna konstrueerimisena. Teiseks, Jakob von Uexkülli omailm, mille abil on võimalik näidata, et elamine tähendab pidevat subjektiks saamist. Lõpuks jõutakse välja tõdemuseni, et biopoliitika 'valitsetavat' saab mõtestada subjektiivse omailmana - mitte aga objektiivse 'elu endana'. 